\title{
Simulation-based Prediction of Structural Design Failure in Fishing Deck Machinery a Hydraulic Type with Finite Element Method
}

\author{
Agri Suwandi ${ }^{*}$, Dede Lia Zariatin, Bambang Sulaksono, Estu Prayogi, and I Made Widana \\ Department of Mechanical Engineering, Faculty of Engineering, Universitas Pancasila, Srengseng \\ Sawah, Jagakarsa, Jakarta 12640, Indonesia
}

\begin{abstract}
The fishing deck machinery is the tools used to collect fish in fishing activities. Fishing deck machinery is intended to improve the effectiveness of fishing operations. The mission of the Ministry of Marine Affairs and Fishery Year 2015-2019 in the Regulation of the Minister of Marine and Fisheries No. 45/PERMEN-KP/2015 which is a priority is to provide assistance for fishing facilities for fishermen; it is necessary to develop and optimize fishing deck machinery. To assure the safety and dependability of these fishing deck machinery, calculations, simulation and functional tests are needed. This paper discusses the prediction of structural failure in the design of fishing deck machinery a hydraulic type with finite element method simulation approach. The results of the FEM simulation analysis are (i) the maximum value of von-Mises stress is greater than the ultimate tensile strength of the material; (ii) $1^{\text {st }}$ principal stress value minimum is smaller than the ultimate tensile strength of material; (iii). the Poisson ratio value higher than the Poisson ratio value of the material. Base on the simulation result, the structural design of fishing deck machinery is safety.
\end{abstract}

Keywords: Failure analysis, fishing aids machine, simulation approach.

\section{Introduction}

Indonesia is the largest archipelago country in the world with approximately 17508 islands and $81290 \mathrm{~km}$ of coastline along the $5800000 \mathrm{~km}^{2}$ coastline composed of archipelagos and territorial waters covering $3100000 \mathrm{~km}^{2}$ and the waters of the Indonesian Exclusive Economic Zone (ZEEI) covering an area of $2700000 \mathrm{~km}^{2}$ [1]. Based on these facts, Indonesia has the huge fishery and marine development potential and become one of the sources for national economic growth. This can occur because of the carrying capacity of [2]: (i) large supply capacity, with the support of increasing demand; (ii) The output of fish and fishery processing industries can be exported, on the other hand the input comes from domestic resources; (iii) Has the potential of a large upstream and downstream industry so that it can absorb a lot of manpower in large numbers; (iv) The product has renewable properties, thus supporting the sustainable development. With an amount of fish,

*Corresponding author: agrisuwandi@univpancasila.ac.id 
fishermen's income should be able to make ends meet. But in reality it is not so, poverty is still part of the life of fishermen. This is due to a deficiency of capital owned by fishermen. One solution that has been performed by the government of one of them is to provide assistance sized fishing vessels 5 Gross Tonnage (GT) to 10 GT so that they can catch fish with a longer reach than previous. Another thing is the cause of low productivity caused by poor fishing skills and knowledge as well as the use of fishing gear and boats is still modest, so the effectiveness and efficiency of the use of fishing gear and other production factors is not optimal. This situation is very influential on income received by fishermen and ultimately also affect the level of welfare. The existence of modern fishing equipment makes the community catch more fish and the time gained from fishing is relatively small $[3,4]$. Fishing deck machinery is a tool that helps the work of fishermen to lift the catch of the fish to the ship. Fishing deck machinery can cut the time needed to lift the catch [5]. This machinery consists of a single and hydraulic type [6,7]. Fishing deck machinery a hydraulic type is a tool that is being the Indonesian government provide assistance to small and medium fishermen.

The development of product design is based on the identification of the needs of the users by considering the current shortage of fishing gear products, such as: the pricing of fishing deck machinery, ease of installation [6, 8], imported components, difficult maintenance processes, safety issue of fishing product [9], and most importantly the construction of fishing deck machinery $[10,11]$. Many designs are not able to support the weight, so the fishing deck machinery had the fracture on the boom.

Based on the background, then do research about fishing deck machinery a hydraulic type easy to use with optimal function and long life of wear. One of the most important things in this fishing deck machinery a hydraulic type is the structure of the fishing deck machinery that capable of holding up to $650 \mathrm{~kg}$ lifting weights [12]. The aim of this paper is a simulation-based prediction of structural design failure in fishing deck machinery hydraulic type with finite element method.

\section{Methods}

Design process analysis is one phase of the process that must be clear before making a product. In this case, the design of fishing deck machinery. The design process analysis consists of design methods that will be used, technical specifications, operational social system and quality options. The outcomes of the design process analysis are applied as a reference in the manufacture of fishing deck machinery.

The drafting begins with a series of customer needs and target specifications and ends with the origination of some product concepts as a final option. By delving into many alternative concepts early in the development process, it may be too late to find a superior concept or a competitor will introduce a product with a better appearance, will be greatly reduced.

Figure 1 shown the simple step of the design process, start from concept design into the prototype product. The process of simulation, start from modelling geometry required fishing deck machinery products that represent the real models. Geometry modelling using CAD software. Features used in the formation of three-dimensional geometry are solid basic features of the model for later assembly of the components available in the inventory of CAD software. Definition of dimensions and specifications of the fishing deck machinery based on the design results with a combination of existing product modifications. FEM simulation by providing the load at the point that secures the most massive burden, then at the bottom of the given area constraint fix. 


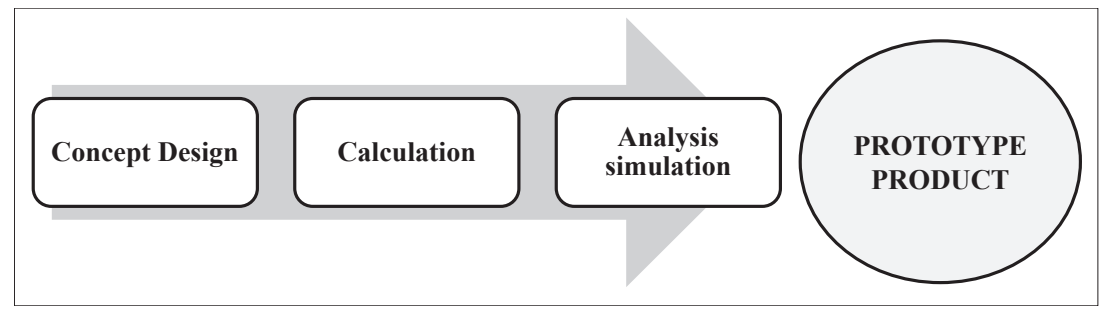

Fig. 1. The step of the design process

The purpose of the simulation analysis process is to reduce the risk of failure of the design of a product prior to the manufacturing process. It can also shorten the time and production costs.

\subsection{Fishing deck machinery description}

Fishing deck machinery is a fishing aids machine used in the operation of fishing gear (Figure 2). The fishing deck machinery designed for the 5 GT to 10 GT fishing boats. Support base, beam and boom components one part that determines the structural strength of the fishing deck machinery (Figure 3). Other supporting components consist of an electric motor, hydraulic cylinder and reel (Kelos) set.

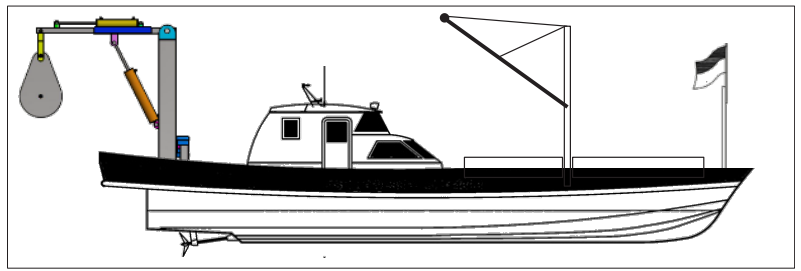

Fig. 2. The position of fishing deck machinery a hydraulic type on 5 GT to 10 GT boat

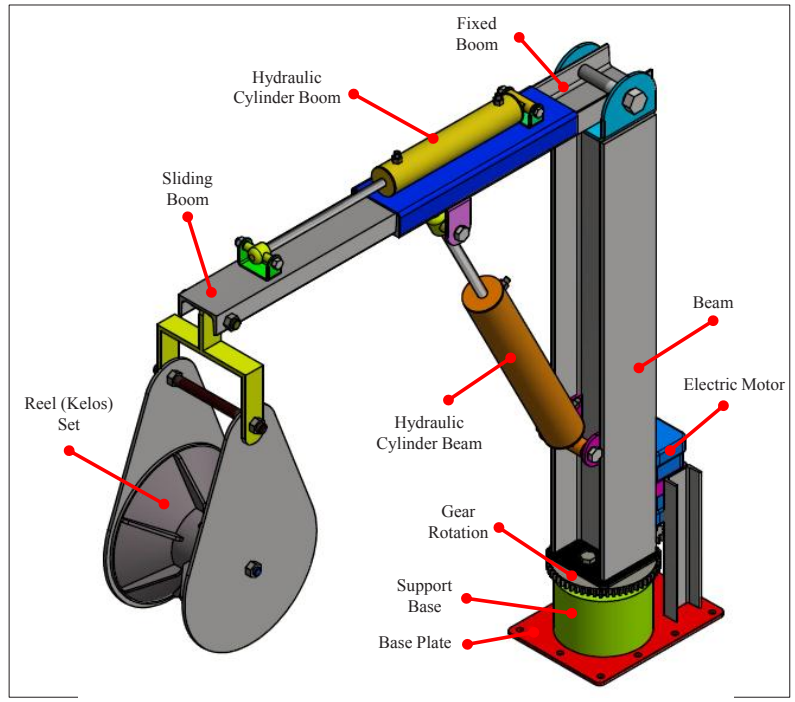

Fig. 3. Component of fishing deck machinery a hydraulic type 


\subsection{Analytical models of fishing deck machinery}

Time Discontinuous Galerkin (TDG) formulations are an ordinary property family of disconnected Galerkin methods that have been introduced in 1973 by Reed \& Hill and Lesaint \& Raviart in 1974 [13]. Basic formulation FEM based on TDG formulation with linear elasticity described Suwandi et al. [14]. In this paper, the extension is generated to the nonlinear case problem.

The materials used as main parameters were aluminium for reel sets and mild steel structures for bracket, beam and boom parts. A material used for boom parts is KS D 3503 $\mathrm{U}$. This material is a type of hot rolled steel for use in structural applications. KS D $3503 \mathrm{U}$ is a material class, and its references are defined in KS. For the beam is used ASTM A6/A6M from ANSI standard. The mechanical properties of mild steel material categories can be seen in Table 1 .

Table 1. Material characteristics of material mild steel structures categories

\begin{tabular}{|c|c|}
\hline Ultimate Tensile Strength & $345 \mathrm{MPa}$ \\
\hline Yield Strength & $207 \mathrm{MPa}$ \\
\hline Young's Modulus & $220 \mathrm{GPa}$ \\
\hline Poisson Ratio & 0.275 \\
\hline
\end{tabular}

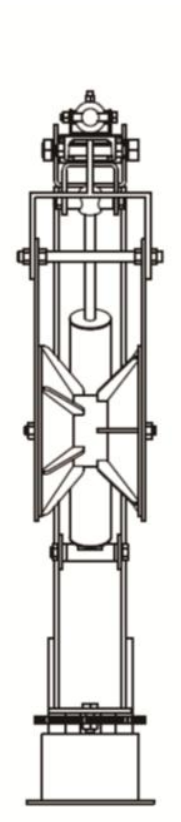

(a) Left view

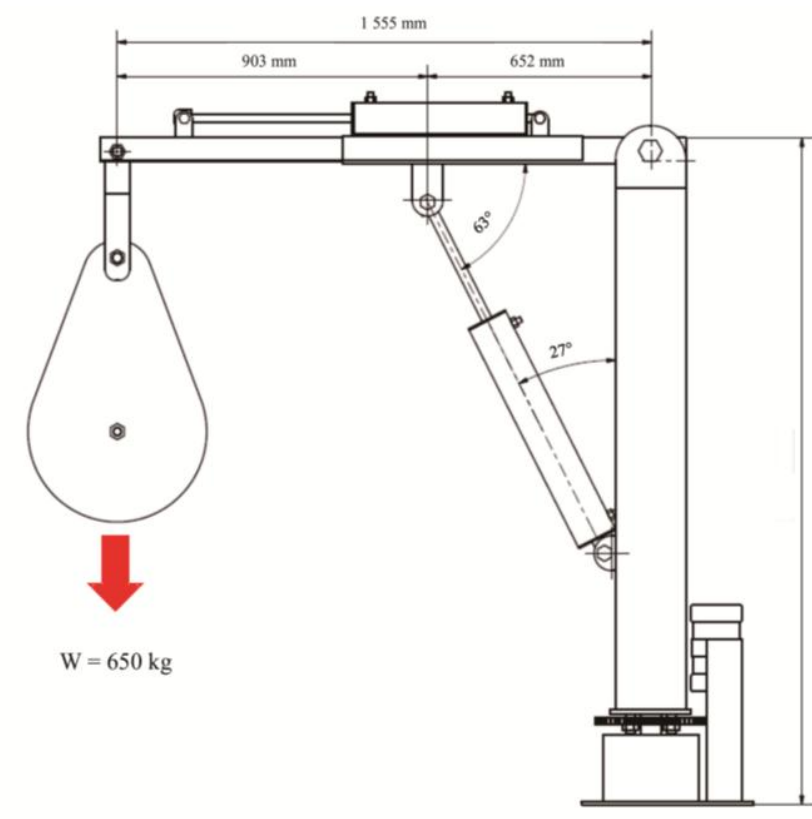

(b) Front view

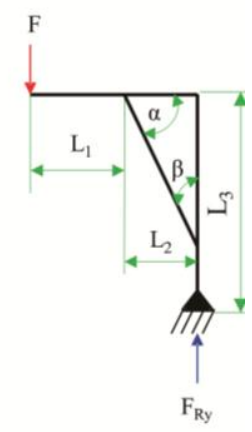

(c) Free Body Diagram

Fig. 4. Idealizing the forces on fishing deck machinery

Figure 4(b) shows the main dimensions of fishing deck machinery with normal height and elongated arm, which has a weight of $650 \mathrm{~kg}$, while the Figure 4(c) displays the free body diagram of fishing deck machinery is a form idealizing model. The load is at the border of the sliding boom with the value $\mathrm{F}=6376.5 \mathrm{~N}$, where the force is the weight of the reel set. The position of $F$ is $1555 \mathrm{~mm}\left(\mathrm{~L}_{1}+\mathrm{L}_{2}\right)$ in the direction of the $\mathrm{x}$-axis with a height of $1918 \mathrm{~mm}$ from the floor in the direction of the $y$-axis $\left(\mathrm{L}_{3}\right)$. 


\section{Results and Discussion}

When the boom has a force, there will be plastic deformation. The simulation results of stress analysis as shown in Figure 5 show the maximum deflection occurs at the end of the fishing deck machinery frame. According to the cantilevered rod theory, if a block has a suddenly changing cross-sectional dimension, then at the point where the change occurs there will be a localized stress concentration. However, this local stress has no significant effect on the calculation of deflection.

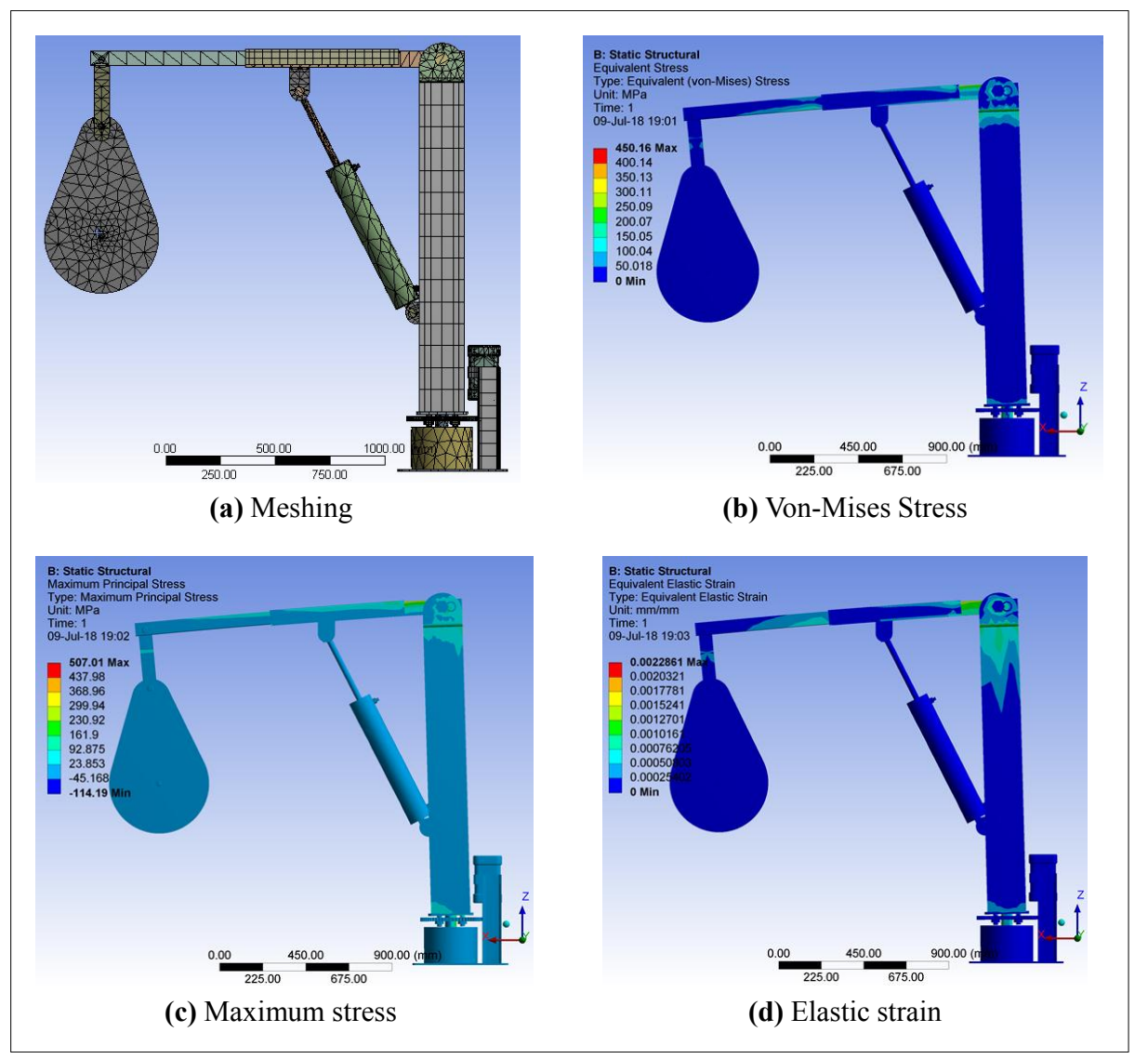

Fig. 5. Stress analysis

The results of the analysis show von-Mises stress of $450.16 \mathrm{MPa}$, a 1 st principal stress value minimum of $114.19 \mathrm{MPa}$, a 3rd principal stress value of $117.84 \mathrm{MPa}$ and the Poisson ratio value is 0.8 The visual analysis shows the critical position is on the connection between the plate of the beam and the fixed boom (see Figure 5). While in the beam position of critical occurs at the top of the beam with a pin fixed boom bracket, it is necessary to note the strength of welding connection between the beam with a pin fixed boom bracket.

Compared to the material characteristics of mild steel structures categories, the greater value of the von-Mises of this material yield strength means that it is necessary to check the design model in the critical area. As for mild steel will a deflection $75 \mathrm{~mm}$ maximum when there is a load of $650 \mathrm{~kg}$ in the middle, with a deflection analysis value of $32 \mathrm{~mm}$ means still allowed. The value of the $1^{\text {st }}$ principal stress minimum and a $3^{\text {rd }}$ principal stress value is 
greater than the yield strength of the material which means the frame design is still within safe limits. For the Poisson ratio of the material is smaller than the Poisson ratio analysis results, in other words, the security level of safety exceeds the design of the material used.

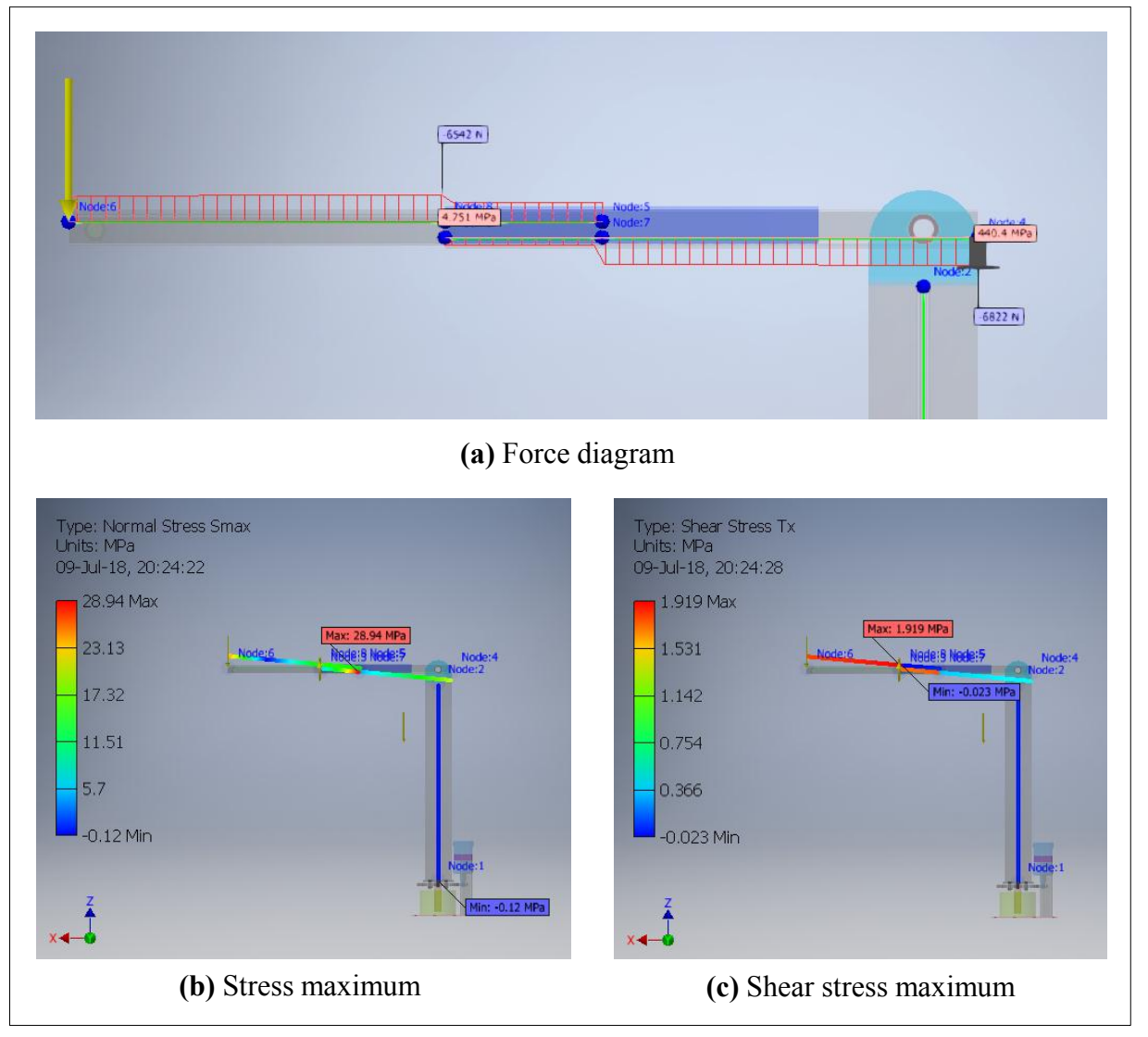

Fig. 6. Frame analysis

To get a more accurate analysis, in addition to stress analysis, it is necessary to simulate frame analysis for the design of fishing deck machinery. Frame analysis in Figure 6(a) shows the location of the deflection at the centre of the boom with the value of the force that occurs $6542 \mathrm{~N}$ at a distance of $500 \mathrm{~mm}$ from the position of a given load. Maximum stress also occurs in the middle of the boom with a maximum stress value of $28.94 \mathrm{MPa}$ (see Figure 6(b)). While Figure 6(c), shows the position of shear stress on the boom that occurred in the middle of the boom with a maximum value of shear stress $1.919 \mathrm{MPa}$. Based on the simulation results, the connection needs to be made strong to withstand the weight of the reel set and catch fish with a rated load of $650 \mathrm{~kg}$.

\section{Conclusion}

In summary, this paper has shown that simulation-based prediction of structural failure design fishing deck machinery a hydraulic type with finite element method can help find structural weaknesses in the design. The results of the FEM simulation analysis: (i) The maximum of von-Mises stress $(450.16 \mathrm{MPa})>$ the Ultimate Tensile Strength of material (345 MPa); (ii). $1^{\text {st }}$ principal stress value minimum of $114.19 \mathrm{MPa}<$ the Ultimate Tensile 
Strength of material $(345 \mathrm{MPa})$, and (iii). The Poisson ratio value $(0.8)>$ The Poisson ratio value of material (0.275). Based on that, the design fishing deck machinery is safety.

\section{Acknowledgements}

Research, design and development activities by the author mention in this paper have been supported by the research grant 'Penelitian Terapan Unggulan Perguruan Tinggi', contract number 008/KM/PNT/2008 from the Ministry of Research Technology and Higher Education of the Republic of Indonesia and LPPM Universitas Pancasila with letters of agreement implementation research number 2104/LPPM/UP/III/2018.

\section{References}

[1] A. S. Tanjung, A. Suwandi. Manufaktur alat bantu penangkapan ikan (fishing deck machinery) produksi dalam negeri [Manufacture fishing deck machinery for domestic production]. Seminar Nasional Sains dan Teknologi, (Jakarta, Indonesia 2017). Seminar Nasional Sains dan Teknologi. [in Bahasa Indonesa]. https://jurnal.umj.ac.id/index.php/semnastek/article/view/2046

[2] R. Cahyadi, A. Suwandi. Perancangan alat bantu penangkap ikan (fishing deck machinery) untuk peningkatan produktifitas nelayan [Fishing deck machinery planning to increase fisherman productivity]. Seminar Nasional Sains dan Teknologi, (Jakarta, Indonesia 2017). Seminar Nasional Sains dan Teknologi. [in Bahasa Indonesia]. https://jurnal.umj.ac.id/index.php/semnastek/article/view/2049

[3] Kementerian Kelautan dan Perikanan Repblik Indonesia, Laut masa depan bangsa kedaulatan, keberlanjutan, kesejahteraan [Ocean is a sovereign, sustainable, and prosperity future of a nation] [Online] from https://kkp.go.id/wpcontent/uploads/2017/12/BUKU_PUTIH_NEW.pdf. (2017). [Accessed on 12 September 2017]. [in Bahasa Indonesia]

[4] Kementerian Kelautan dan Perikanan Badan Riset dan Sumber Daya Manusia Kelautan dan Perikanan, Peraturan Kepala Badan Riset dan Sumber Daya Manusia Kelautan dan Perikanan nomor 13/PER-BRSDM/2017 tentang rencana strategis badan riset dan sumber daya manusia kelautan dan perikanan tahun 2017-2019 [Regulation of the head of marine and fisheries research and human resources number 13 / PER-BRSDM / 2017 concerning strategic plans for research bodies and marine and fisheries human resources 2017-2019] [Online] http://kkp.go.id/ancomponent/media/upload-gambarpendukung/brsdm/SAKIP/02.1\%20Renstra\%20BRSDM_awal.pdf. (2017). [Accessed on 28 August 2017]. [in Bahasa Indonesia].

[5] BSN. Istilah dan definisi - Bagian 13: Alat bantu penangkapan ikan [Part 13 : Fishing aids] (SNI 7277.13:2008). Badan Standardisasi Nasional Indonesia. Jakarta (2008). [in Bahasa Indonesia]. http://bkipm.kkp.go.id/bkipmnew/v2016/sni_list.php?j=SNI-PERIKANAN-TANGKAP \&m=SNI++PERIKANAN+TANGKAP. $[$ [Accessed on August 28, 2017]

[6] M. N. Mosdell. Line Hauler with Dualler Plate and Line Coiler United States of America Patent US 20130341578 A1 from https://patents.google.com/patent/US20130341578?oq=US+20130341578+A1. (2013). [Accessed on 15 November 2017] 
[7] Deep Drop Commercial, Electrics line haulers [Online] from https://www.deepdropcommercial.com/fishing-equipment/line-haulers/electric-linehaulers/ (2017). [Accessed on 11 April 2017].

[8] Dehong Z, Automatic net hauler China Patent CN1344491A from https://patents.google.com/patent/CN1344491A/en (2002). [Accessed on 15 November 2017]

[9] Yong X. Safe type fishing boat net hauling device China Patent CN102673745B from https://patents.google.com/patent/CN102673745B (2014). [Accessed on 15 November 2017]. [translate from Chinese]

[10] Zhuojun G., Zhiqiang X., Tao J., Zhiyong W., Zhixin C., Bo D., et al. Marine fishing single ship bag seine net hauler China Patent CN 102501947 A from https://patents.google.com/patent/CN102501947A/zh (2012). [Accessed on November 15, 2017]. [translate from Chinese]

[11] Zhihong M. Fishing with a wire pulling device China Patent CN 102907381 B from https://patents.google.com/patent/CN102907381B/en (2015). [Accessed on November 15, 2017]

[12] BSN. Istilah dan definisi - Bagian 9: Jaring angkat [Part 9: Lifting nets] (SNI 7277.9:2008). Badan Standardisasi Nasional Indonesia. Jakarta (2008). http://www.bkipm.kkp.go.id/bkipmnew/sni/index/SNI\%20\%20PERIKANAN\%20TA NGKAP. [Accessed on August 28, 2017]

[13] S. Wada, Rui Z., S. R. Mannava, V. K. Vasudevan, Dong Q. Finite Elements in Analysis and Design, $138: 21-30(2018)$. https://www.sciencedirect.com/science/article/pii/S0168874X17305140?via\%3Dihub

[14] A. Suwandi, T.P. Soemardi, G. Kiswanto, W. Kusumaningsih, I. Gusti Agung I.G.W. Development of friction and wear full-scale testing for TKR prostheses with reliable low cost apparatus. International Symposium on Biomedical Engineering 2017 (Denpasar, Indonesia 2017). AIP Conference Proceedings, 1933,020003 (2018). https://aip.scitation.org/doi/abs/10.1063/1.5023937 